\title{
The Relationships among Tourist Novelty, Familiarity, Satisfaction, and Destination Loyalty: Beyond the Novelty-familiarity Continuum
}

\author{
Masaki Toyama ${ }^{1} \&$ Yuichi Yamada ${ }^{1}$ \\ ${ }^{1}$ Tourism Research Department, Japan Travel Bureau Foundation, Tokyo, Japan \\ Correspondence: Masaki Toyama, Tourism Research Department, Japan Travel Bureau Foundation, 2-6-1 \\ Otemachi, Chiyoda-ku, Tokyo, Japan. E-mail: toyama@jtb.or.jp
}

\author{
Received: August 28, 2012 Accepted: September 12, 2012 Online Published: November 2, 2012 \\ doi:10.5539/ijms.v4n6p10 URL: http://dx.doi.org/10.5539/ijms.v4n6p10
}

\begin{abstract}
Novelty and familiarity play an important role in tourists' perceptions, and these have been regarded as contrasting concepts for a long time. However, recent cognitive science literature suggests that novelty and familiarity are separate concepts, independently influencing consumer behavior. Based on this, our study aims to examine the differences between the effects of novelty and familiarity on satisfaction and destination loyalty. These relationships are explored by analyzing the responses of tourists in Takayama City, Japan. The research model was tested using structural equation modeling (SEM) techniques. The results show that both novelty and familiarity contribute to destination loyalty; however, only novelty has an effect on the formation of satisfaction. Theoretical and managerial implications of these are also discussed.
\end{abstract}

Keywords: novelty, familiarity, satisfaction, destination loyalty

\section{Introduction}

As the tourism market becomes increasingly competitive, the importance of customer retention has also increased. Studies indicate that a 5\% increase in customer retention could result in company profits rising by $25 \%-85 \%$ over the lifetime of a customer (Reichheld \& Sasser, 1990; Shoemaker \& Lewis, 1999). In addition, the marketing cost of retaining existing customers is much lower than that of gaining new customers (Rosenberg \& Czepiel, 1984). In terms of consumer behavior, customer retention leads to positive word-of-mouth referral for customer's friends, relatives, and other potential customers (Shoemaker \& Lewis, 1999). Loyalty is one of the major indicators used to measure customer retention. For tourism destination marketing, tourists' loyalty towards a destination (hereafter referred to as "destination loyalty") can be defined as tourists' intention to revisit and recommend the destination to others (Yoon \& Uysal, 2005). Several studies have attempted to identify factors affecting destination loyalty. For example, past studies revealed the effects of satisfaction (Chen \& Tsai, 2007; Chi \& Qu, 2008; Prayag \& Ryan, 2012; Yoon \& Uysal, 2005), destination image (Chen \& Tsai, 2007), trip quality (Chen \& Tsai, 2007; Yamada \& Toyama, 2011), previous visitation experience (Petrick \& Sirakaya, 2004; Chi, 2012), emotion (Bosque \& Martin, 2008; Yamada \& Toyama, 2011), motivation (Yoon \& Uysal, 2005; Mechinda, Serirat, \& Guild, 2009), and destination attachment (Prayag \& Ryan, 2012; A. Yuksel, F. Yuksel, \& Bilim, 2010) on destination loyalty. Amongst these, satisfaction seems to be the most frequently occurring measure.

However, few studies have investigated the effects of destination familiarity, which plays an important role in tourists' perception. Although Mechinda et al. (2009) showed that familiarity influences destination loyalty, they did not examine the relationships among familiarity, satisfaction, and destination loyalty. If tourists feel a sense of familiarity, it can provide a feeling of security and comfort, which may lead to satisfaction and loyalty. On the one hand, novelty-seeking is regarded as a key component of travel motivation (Crompton, 1979). It is also an antecedent of satisfaction and destination loyalty (Assaker, Vinzi, \& O'Connor, 2011; Feng \& Jang, 2007).

According to these propositions, even though tourists seek novelty, they prefer to visit familiar destinations. This appears to be inconsistent on the surface. Indeed, novelty and familiarity have been treated as contrasting concepts in tourism research since the 1970s. For example, Cohen (1972) classified four types of tourists based on their preference for either familiarity or novelty. This could be restated as the "novelty-familiarity continuum" (Basala \& Klenosky, 2001). However, in recent cognitive science literature, Shimojo (2008) suggested that novelty and familiarity are distinct concepts, which independently influence consumer behavior. Given the above 
considerations, novelty and familiarity could be regarded as separate concepts, which independently influence satisfaction and destination loyalty.

Overall, the main purpose of this study is to examine the differences between the effects of novelty and familiarity on satisfaction and destination loyalty. In doing so, this study focuses on providing an integrated understanding of tourist novelty and familiarity.

\section{Literature Review}

\subsection{Destination Loyalty}

Loyalty is defined as a "deeply held commitment to re-buy or re-purchase a preferred product/service consistently in the future, thereby causing repetitive same-brand or same brand set purchasing, despite situational influences and marketing efforts having the potential to cause switching behavior" (Oliver, 1999). In general, loyalty has been measured through the following approaches: (1) the behavioral approach, (2) the attitudinal approach, and (3) the composite approach (Jacoby \& Chestnut, 1978). The behavioral approach is based on actual consumption, such as sequence of purchase, proportion of patronage, and probability of purchase. It has been indicated that this approach only produces the static outcome of the dynamic process, and does not attempt to explain the factors that affect loyalty (Dick \& Basu, 1994; Yoon \& Uysal, 2005). In the attitudinal approach, loyalty measures a consumer's strength of affection towards a brand (Backman \& Crompton, 1991). This approach is based on consumer brand preferences or intention to buy the brand. Finally, the composite approach is an integration of behavioral and attitudinal dimensions. Oppermann (2000) noted that the composite approach has serious limitations "simply because of the weighting applied to both behavioral and attitudinal components as well as to the various components within each of those."

In tourism, destination loyalty was measured using only the behavioral approach in earlier studies (e.g., Oppermann, 2000). However, recently, the attitudinal approach has been acknowledged as an adequate measure for assessing destination loyalty (Bosque \& Martin, 2008; Chi \& Qu, 2008; Yoon \& Uysal, 2005). In these studies, destination loyalty has been measured as tourists' intention to revisit the same destination, and their intention to recommend the destination to others. Therefore, the present study uses the attitudinal approach to measure destination loyalty.

\subsection{Satisfaction}

In the services industry, satisfaction is defined as "an overall evaluation of a customer's experiences with a service provider, as opposed to a transaction-specific satisfaction judgment" (Han, Back, \& Barrett, 2009). There are two approaches to measure satisfaction. The first is based on specific-transaction, and the second is based on overall satisfaction (Roig, Garcia, \& Tena, 2009). Specific-transaction is described as a customer's evaluation of consumption experience with and reactions to a particular product transaction, episode, or service encounter (Olsen \& Johnson, 2003). Overall satisfaction is described as a customer's overall evaluation of a product or service provider to date (Olsen \& Johnson, 2003). Typically, overall satisfaction is a more stable concept than the specific-transaction approach (Parasuraman, Zeithmal, \& Berry, 1994).

In marketing literature, there are empirical evidences that satisfaction is a strong indicator of repeat purchases and recommendation of the products or services to others, which are the main components of loyalty (Anderson \& Sullivan, 1993; Taylor \& Baker, 1994). Likewise, a number of empirical works revealed that satisfaction has a positive influence on destination loyalty (Bosque \& Martin, 2008; Chi \& Qu, 2008; Prayag \& Ryan, 2012; Yoon \& Uysal, 2005). If tourists are satisfied with their vacation experience, they are more likely to return to the same destination and to recommend that destination to other people.

\subsection{Novelty}

Generally, novelty is defined as the degree of contrast between present perception and past experience (Pearson, 1970). From one perspective of the definition, it is possible to understand that tourists want to experience something novel through their travel. Indeed, as mentioned above, novelty-seeking is the central component of travel motivation and influences tourists' decision-making process (Crompton, 1979; Petrick, 2002). Crompton (1979) treated novelty as a new experience but not necessarily as new knowledge. Lee and Crompton (1992) showed that the novelty construct comprises the following four dimensions: thrill, adventure, surprise, and boredom-alleviation. In the context of marketing, novelty-seeking relates to variety-seeking, which is the tendency for consumers to switch away from a choice made on the most recent occasion (Ratner, Kahn, \& Kahneman, 1999). According to Feng and Jang (2007), both theories are based on the common notion that consumers seek optimal levels of stimulation when they make a choice (Hebb \& Thompson, 1954).

Novelty-seeking has a positive influence on satisfaction (Assaker et al., 2011). If tourists seek novelty and the 
experience meets or exceeds their expectations, they will be satisfied. Furthermore, Feng and Jang (2007) established a positive relationship between novelty-seeking and revisit intention. As indicated above, revisit intention is the component of destination loyalty. Interestingly, however, very few studies have measured the novelty towards a destination as an evaluation of tourist experience. This can be explained by the proposition that novelty is the contrary concept to familiarity (Lee \& Crompton, 1992). Based on this assumption, it is not necessary to measure novelty when researchers measure destination familiarity. However, this study views novelty and familiarity as distinct concepts. If tourists feel a sense of novelty when visiting a destination, they will be satisfied and the destination may be perceived as an attractive place. This may lead to destination loyalty.

\subsection{Familiarity}

Familiarity has been regarded as a consumer's knowledge construct (Park, Mothersbaugh, \& Feick, 1994). More specifically, familiarity is defined as the number of product-related experiences (Alba \& Hutchinson, 1987) or the amount of product-related information (Rao \& Sieben, 1992). In tourism, Baloglu (2001) proposed that familiarity with a destination is operationalized as a combination of the amount of information and previous experience. Similar to destination loyalty, familiarity has been measured using behavioral and attitudinal approaches. The behavioral approach is based on actual experience, and the attitudinal approach is based on self-reported measure. Although several studies have used the behavioral approach (e.g., Milman \& Pizam, 1995; Baloglu, 2001), this approach has a limitation in that it is hard to capture varying degrees and kinds of tourist experiences (Kim \& Richardson, 2003). Therefore, this study uses the attitudinal approach.

A number of studies reveal that familiarity affects various aspects of tourist behavior. For instance, familiarity influences the tourists' information search process. D. Snepenger and M. Snepenger (1993) showed that travelers who are very familiar with a destination tend not to rely on external information sources. From another stand-point, Baloglu (2001) determined a positive relationship between familiarity and destination image. Milman and Pizam (1995) also showed that familiarity influences the likelihood of visitation. Likewise, destination loyalty is affected by familiarity (Mechinda et al., 2009).

\subsection{Relationships between Novelty and Familiarity}

Cohen (1972) classified four types of tourists based on their preference for either familiarity or novelty; the organized mass tourist, the individual mass tourist, the explorer, and the drifter. The organized mass tourist seeks to minimize exposure to novelty and prefers familiarity at a maximum. The individual mass tourist and the explorer tend to prefer a blend of familiarity and novelty. The drifter seeks to novelty at a maximum, and avoids the regular tourist route. Subsequently, many studies used this approach to understand tourist behavior (e.g., Basala \& Klenosky, 2001).

On the one hand, recent cognitive science research illustrates that novelty and familiarity are separate and segregated concepts. Shimojo (2008) conducted an experiment to investigate the attitudes toward advertisements. Participants were asked to watch a TV commercial and evaluate its perceived novelty, familiarity and overall attractiveness. The results showed that both novelty and familiarity influence the judgment of attractiveness of TV commercial. From the results of his study, novelty and familiarity were not significantly correlated with each other. In addition, Park, E. Shimojo, and S. Shimojo (2010) showed a segregation of novelty and familiarity preference between the object categories. Novelty preference is dominant in natural scenes, and familiarity preference is dominant in human faces. However, there are very few studies in tourism literature that have examined the relationships between novelty and familiarity as separate constructs.

Based on the above information, the following null hypotheses were tested:

H01a: There is no relationship between tourist novelty and satisfaction.

H01b: There is no relationship between tourist novelty and destination loyalty.

H02a: There is no relationship between tourist familiarity and satisfaction.

H02b: There is no relationship between tourist familiarity and destination loyalty.

H03: There is no relationship between satisfaction and destination loyalty.

\section{Method}

\subsection{Study Site}

The data for this study was collected in Takayama City, Japan. Takayama City is located in the central part of Japan, close to the Hida mountains (a part of Chubu Sangaku National Park) and Shirakawa-go (designated as a UNESCO world heritage site). The city is famous for its historical landscape. In the preservation areas of the city, 
there are many traditional buildings and homes dating back to the Edo Period $\left(17^{\text {th }}-19^{\text {th }}\right.$ century). The atmosphere attracts a number of domestic and international tourists.

\subsection{Questionnaire}

The questionnaire consisted of five sections: novelty, familiarity, satisfaction, destination loyalty, and socio-demographic information. Novelty was measured using four items on a 7-point scale (strongly disagree $=$ 1; strongly agree $=7$ ) based on novelty-seeking measures (Lee \& Crompton, 1992; Feng \& Jang, 2007). These four items were as follows: (a) This destination offers an unusual experience; (b) This destination offers new discoveries; (c) This destination offers new experiences; and (d) This destination is new for me. Familiarity was measured using four items on a 7-point scale (strongly disagree $=1$; strongly agree $=7$ ) adapted from Mechinda et al. (2009). These four items were as follows: (a) I know a lot about this destination; (b) I know more than others about this destination; (c) This destination feels familiar to me; and (d) I feel close to this destination. Based on Chi and Qu (2008) and Prayag and Ryan (2012), a single-item measure for overall satisfaction was used in this study, using a 7-point scale (very dissatisfied $=1$; very satisfied $=7$ ). This item was as follows: "Overall, how satisfied were you with your visit?" Destination loyalty was measured using two items-intention to revisit and intention to recommend - on a 7-point scale (strongly disagree $=1$; strongly agree $=7$ ). These two items were as follows: (a) Would you like to visit this location again within a year? and (b) Would you recommend this location to your close friends? Finally, socio-demographic information included questions on gender, age, length of stay, and travel companion, etc. The questionnaire was originally written in Japanese, and then translated into English by native speakers. The back-translation was conducted to ensure that the meaning of the original questionnaire was retained.

\subsection{Data Collection}

The data for this study was collected through a self-administered questionnaire method, conducted from July 2011 to September 2011. The target population was domestic tourists who were able to read Japanese. Overall, 1,500 questionnaires were distributed in major tourist attractions of the destination using equal-interval sampling method. After the elimination of incomplete responses, 545 usable responses were obtained with a response rate of $36.3 \%$. Amongst the respondents, $54.7 \%$ were male and the average age of the respondents was between $40-49$ years.

\section{Results}

Structural equation modeling (SEM) was used to test the hypotheses in this study. All analyses were conducted using R version 2.13.1 and the packages "psych" and "sem."

\subsection{Scale Development}

Prior to SEM analyses, an exploratory factor analysis (EFA) was conducted to establish the scale of novelty and familiarity. As indicated above, very few studies have measured tourist novelty and familiarity at the same time. Additionally, this procedure was performed to decrease multicollinearity amongst indicators in the measurement model. The principle axis factor method was used to extract the underlying factors amongst eight attributes (see Table 1). As a result, the scree plot indicated a two-factor solution. The two factors were labeled as novelty and familiarity, and varimax rotation revealed that all items had factor loadings of 0.40 or greater, which was the general cut-off criterion (Worthington \& Whittaker, 2006). One item from familiarity ("I feel close to this destination") was excluded from subsequent analyses for cross-loadings. Then, the Cronbach's alphas for the two factors were calculated to assess the reliability of the scale. The alpha values ranged from 0.90 to 0.92 , exceeding the minimum required level of 0.60 (Nunnally \& Bernstein, 1994).

Table 1. The results of EFA

\begin{tabular}{llll}
\hline & $\begin{array}{l}\text { Factor1: } \\
\text { Novelty }\end{array}$ & $\begin{array}{l}\text { Factor2: } \\
\text { Familiarity }\end{array}$ & Communality \\
\hline This destination offers an unusual experience & $\mathbf{0 . 8 6}$ & 0.09 & 0.75 \\
This destination offers new experiences & $\mathbf{0 . 8 6}$ & 0.12 & 0.75 \\
This destination offers new discoveries & $\mathbf{0 . 8 6}$ & 0.13 & 0.75 \\
This destination is new for me & $\mathbf{0 . 8 3}$ & 0.06 & 0.70 \\
I know a lot about this destination & 0.02 & $\mathbf{0 . 9 4}$ & 0.89 \\
I know more than others about this destination & 0.01 & $\mathbf{0 . 8 6}$ & 0.73 \\
This destination feels familiar to me & 0.18 & $\mathbf{0 . 8 0}$ & 0.67 \\
I feel close to this destination & 0.45 & 0.53 & 0.50 \\
Variance explained (\%) & 39.4 & 32.2 & \\
\hline
\end{tabular}




\subsection{Measurement Model}

Confirmatory factor analysis (CFA) was conducted to examine the reliability and convergent/discriminant validity of the measurement model (Anderson \& Gerbing, 1988). It would seem inappropriate to conduct a CFA after an EFA on the same data. However, it is acknowledged that when there is not sufficient theoretical basis, EFA and CFA could both be used to test the same data for cross-validation purposes (Fabrigar et al., 1999; Van Prooijen \& Van der Kloot 2001; Worthington \& Whittaker, 2006). Additionally, satisfaction was not included in the analysis, as it was composed of a single item. Chi-square value, goodness-of-fit-index (GFI), comparative fit index (CFI), normed fit index (NFI), and root mean square of approximation (RMSEA) were used to assess the quality of the measurement model. The results of CFA are shown in Table 2. The goodness-of-fit indices indicate that the model adequately fit the data $(\mathrm{GFI}=0.92, \mathrm{CFI}=0.94, \mathrm{NFI}=0.93, \mathrm{RMSEA}=0.12)$. The chi-square statistic was significant $\left(\chi^{2}=209.83, \mathrm{df}=24, p<0.01\right)$ owing to large sample sizes. The composite reliabilities of constructs (novelty, familiarity, and destination loyalty) exceeded the recommended level of 0.60 , showing construct reliability (Bagozzi \& Yi, 1988). The $t$ values of all measurement items exceeded the critical level of $1.96(p<0.05)$. In addition, standardized coefficients for all measurement items exceeded 0.5 . These findings provide evidence of convergent validity (Steenkamp \& Van Trijp, 1991). Finally, the average variance extracted (AVE) for all constructs was higher than the square of the correlation between the two constructs. Therefore, discriminant validity was confirmed (Fornell \& Larcker, 1981).

Table 2. The results of CFA

\begin{tabular}{|c|c|c|c|c|c|}
\hline & $\begin{array}{l}\text { Standardized } \\
\text { loading }\end{array}$ & t value & $\begin{array}{l}\text { Composite } \\
\text { reliability }\end{array}$ & AVE & Label \\
\hline Novelty & & & 0.92 & 0.74 & \\
\hline This destination offers an unusual experience & 0.85 & 24.0 & & & NV1 \\
\hline This destination offers new experiences & 0.88 & 25.6 & & & NV2 \\
\hline This destination offers new discoveries & 0.88 & 25.7 & & & NV3 \\
\hline This destination is new for me & 0.83 & 23.0 & & & NV4 \\
\hline Familiarity & & & 0.90 & 0.76 & \\
\hline I know a lot about this destination & 0.96 & 29.0 & & & FM1 \\
\hline I know more than others about this destination & 0.88 & 25.1 & & & FM2 \\
\hline This destination feels familiar to me & 0.75 & 20.0 & & & FM3 \\
\hline Destination loyalty & & & 0.63 & 0.48 & \\
\hline Intention to recommend & 0.83 & 14.9 & & & LOY1 \\
\hline Intention to revisit & 0.52 & 10.8 & & & LOY2 \\
\hline
\end{tabular}

\subsection{Structural Model}

The structural model was estimated using the maximum-likelihood method (see Figure 1). Although the chi-square statistic was significant $\left(\chi^{2}=233.2, \mathrm{df}=31, p<0.01\right)$, the goodness-of-fit indices indicated that the model adequately fit the data $(\mathrm{GFI}=0.92, \mathrm{CFI}=0.94, \mathrm{NFI}=0.93$, RMSEA $=0.11)$. Novelty had a direct effect on overall satisfaction $(\beta=0.54, p<0.01)$ and destination loyalty $(\beta=0.28, p<0.01)$. Thus, H01a and H01b were rejected. Familiarity had a direct effect on destination loyalty $(\beta=0.11, p<0.05)$. In addition, overall satisfaction had a direct influence on destination loyalty $(\beta=0.59, p<0.01)$. As a result, H02b and H03 were rejected. However, the relationship between familiarity and overall satisfaction was not significant $(\beta=-0.07$, n.s), and therefore, H02a was not rejected. 


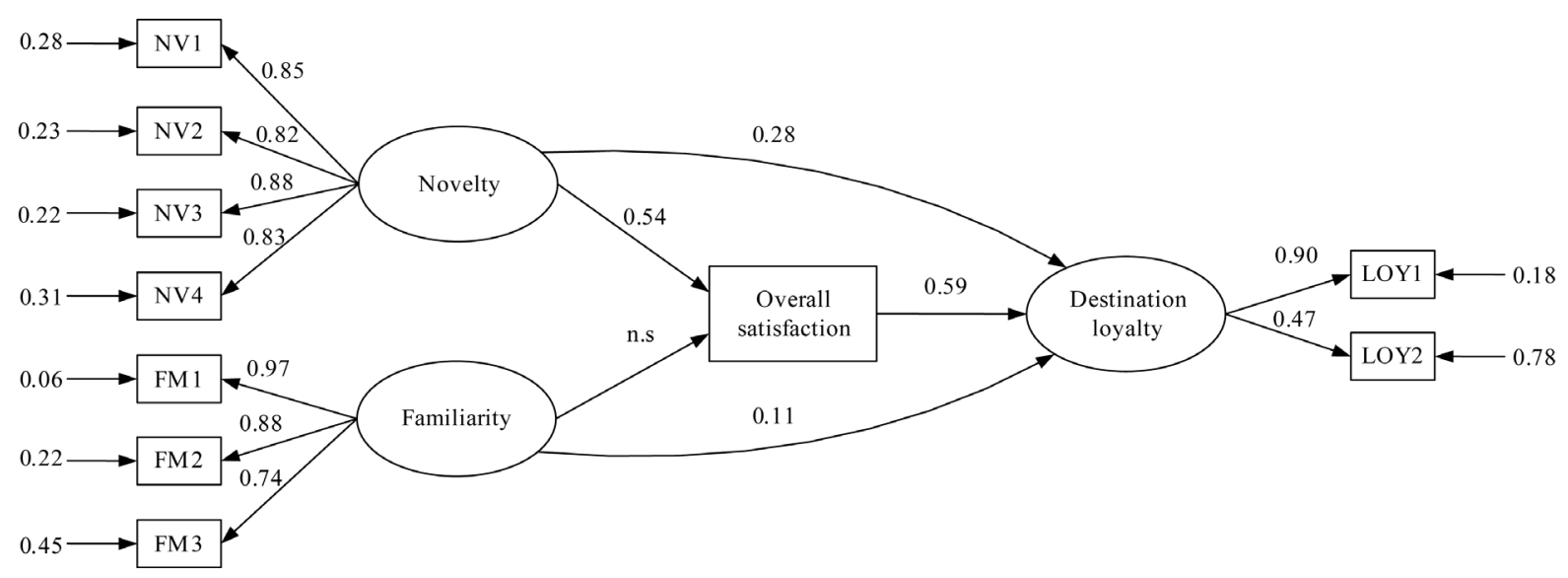

Figure 1. The structural model

\section{Discussion}

Novelty and familiarity were treated as distinct concepts in this study. The SEM analysis confirmed the causal relationships amongst tourist novelty, familiarity, satisfaction, and destination loyalty. From a theoretical perspective, the results of the present study extended the framework of tourist novelty and familiarity. In tourism literature, novelty and familiarity have been considered as contrary constructs. However, this study provided empirical evidence that novelty and familiarity can be seen as mutually separate constructs. The results are consistent with the findings of Shimojo (2008), suggesting that his theory of consumer behavior can be applicable to tourist behavior. In the field of destination marketing, it would be useful for tourism researchers to examine novelty and familiarity separately, as done in this study. The procedure may offer new insights into understanding the complex behaviors of tourists.

In terms of hypotheses testing, the results indicated that both novelty and familiarity contribute to the formation of destination loyalty. Perception of novelty could contribute to developing the awareness of the area as a tourist destination, thereby reinforcing loyalty (Pike, Bianchi, Kerr, \& Patti, 2010). Alternatively, it is likely that many tourists cannot experience all aspects of the destination during a single stay. In the context of sampling, the average Japanese stay was less than two nights per trip (Jalan Research Center, 2011). If tourists recognize novelty, they may want to experience the remaining parts of the destination. In addition, it is suggested that the effect of familiarity on destination loyalty was influenced by the desire to reduce the risk of unsatisfactory experiences (Gitelson \& Crompton, 1984). Then, the positive relationship between novelty and destination loyalty was mediated by satisfaction. The relationship between satisfaction and loyalty in this study is consistent with those suggested in previous studies (Chen \& Tsai, 2007; Chi \& Qu, 2008; Prayag \& Ryan, 2012; Yoon \& Uysal, 2005). Perception of novelty promotes the fulfillment of novelty-seeking, and this may lead to satisfaction. The results also showed that no significant relationship existed between familiarity and satisfaction. Overall, these findings suggest that novelty is more influential in forming destination loyalty than familiarity. Moreover, it is possible that tourists want to experience new things in familiar destinations.

In order to create a competitive advantage, destination marketers should emphasize that their destination offers something new to target markets. One way to do this is by developing new tourist attractions or events. Another way is by giving new meaning to the destination. Communication strategies must be utilized to gain recognition for their efforts. At the same time, they should also enhance tourist familiarity with their destination by providing sufficient information (through advertising, public relations, tourist information centers, etc.).

It must be noted that this study is subject to several limitations. First, this study does not examine the effects of socio-demographic characteristics. Repeat tourists may place more emphasis on familiarity and less on novelty (Gitelson \& Crompton, 1984). Therefore, it is recommended that both behavioral and attitudinal approaches are used to measure tourist familiarity. Second, this study was conducted at a specific destination. Replication of these results in other destinations is needed to generalize the findings. Third, this study does not consider factors such as novelty-seeking and other motivational variables. We have to refer to the study of tourist typologies in order to consider individual differences in motivation. Future research needs to be conducted to improve the research model. 


\section{Acknowledgements}

This study was supported by Society of Destination Management Research (SDMR) of Japan Travel Bureau Foundation.

\section{References}

Alba, J. W., \& Hutchinson, J. W. (1987). Dimensions of consumer expertise. Journal of Consumer Behavior, 13, 411-454.

Anderson, J. C., \& Gerbing, D. W. (1988). Structural equation modeling in practice: A review and recommended two-step approach. Psychological Bulletin, $411-423$. http://dx.doi.org/doi/10.1037/0033-2909.103.3.411

Anderson, E. W., \& Sullivan, M. W. (1993). The antecedents and consequences of customer satisfaction for firms. Marketing Science, 12, 125-143. http:// dx.doi.org/doi/10.1287/mksc.12.2.125

Assaker, G., Vinzi, V. E., \& O’Connor, P. O. (2011). Examining the effect of novelty seeking, satisfaction, and destination image on tourists' return pattern: A two factor, non-linear latent growth model. Tourism Management, 32(4), 890-901. http://dx.doi.org/10.1016/j.tourman.2010.08.004

Backman, S. J., \& Crompton, J. L. (1991). The Usefulness of selected variables for predicting activity loyalty. Leisure Sciences, 13, 205-222. http://dx.doi.org/10.1080/01490409109513138

Bagozzi, R. P., \& Yi, Y. (1988). On the evaluation of structural equation models. Journal of the Academy of Marketing Science, 16(1), 74-94. http://dx.doi.org/10.1177/009207038801600107

Baloglu, S. (2001). Image variations of Turkey by familiarity index: Informational and experiential dimensions. Tourism Management, 22(2), 127-133. http://dx.doi.org/10.1016/S0261-5177(00)00049-2

Basala, S., \& Klenosky, D. B. (2001). Travel style preferences for visiting a novel destination: A conjoint investigation across the novelty-familiarity continuum. Journal of Travel Research, 40(2), 172-182. http://dx.doi.org/10.1177/004728750104000208

Bosque, I. R., \& Martín, H. S. (2008). Tourist satisfaction: A cognitive-affective model. Annals of Tourism Research, 35(2), 551-573. http://dx.doi.org/10.1016/j.annals.2008.02.006

Chen, C. F., \& Tsai, D. (2007). How destination image and evaluative factors affect behavioral intentions? Tourism Management, 28(4), 1115-1122. http://dx.doi.org/10.1016/j.tourman.2006.07.007

Chi, C. G. Q., \& H. Qu. (2008). Examining the structural relationships of destination image, tourist satisfaction and destination loyalty: An integrated approach. Tourism Management, 29(4), 624-636. http://dx.doi.org/10.1016/j.tourman.2007.06.007

Chi, C. G. Q. (2012). An examination of destination loyalty differences between first-time and repeat visitors. Journal of Hospitality \& Tourism Research, 36(1), 3-24. http://dx.doi.org/10.1177/1096348010382235

Cohen, E. (1972). Towards a sociology of international tourism. Sociological Research, 39, 164-182.

Crompton, J. (1979). Motivations for pleasure vacation. Annals of Tourism Research, 6, $408-424$. http://dx.doi.org/10.1016/0160-7383(79)90004-5

Dick, A., \& Basu, K. (1994). Customer loyalty: Toward an integrated conceptual framework. Journal of the Academy of Marketing Science, 22(2), 99-113. http://dx.doi.org/10.1177/0092070394222001

Fabrigar, L. R., Wegener, D. T., MacCallum, R. C., \& Strahan, E. J. (1999). Evaluating the use of exploratory factor analysis in psychological research. Psychological Methods, 4, 272-299.

Feng, R., \& Jang, S. (2007). Temporal destination revisit intention: The effects of novelty seeking and satisfaction. Tourism Management, 28(2), 580-590. http://dx.doi.org/10.1016/j.tourman.2006.04.024

Fornell, C., \& Larcker, D. F. (1981). Evaluating structural equation models with unobservable variables and measurement error. Journal of Marketing Research, 18, 39-50.

Gitelson, R. J., \& Crompton, J. L. (1984). Insights into the repeat vacation phenomenon. Annals of Tourism Research, 11(2), 199-217. http://dx.doi.org/10.1016/0160-7383(84)90070-7

Han, H., Back, K. J., \& Barrett, B. (2009). Influencing factors on restaurant customers' revisit intention: The roles of emotions and switching barriers. International Journal of Hospitality Management, 28, 563-572. http://dx.doi.org/10.1016/j.ijhm.2009.03.005

Hebb, D. O., \& Thompson, W. R. (1954). The social significance of animal studies. In G. Lindzey (Ed.), 
Handbook of Social Psychology (pp. 551-552). Reading, Mass: Addison-Wesley.

Jacoby, J., \& Chestnut, R. (1978). Brand loyalty: Measurement and management. New York: John Wiley.

Jalan Research Center. (2011). Jalan travel and accommodation survey 2011 (in Japanese). Retrieved from http://www.recruit.jp/news_data/data/travel_gourmet/20110721.pdf

Kim, H., \& Richardson, S. (2003). Motion picture impacts on destination images. Annals of Tourism Research, 30(1), 216-237. http://dx.doi.org/10.1016/S0160-7383(02)00062-2

Lee, T. H., \& Crompton, J. (1992). Measuring novelty seeking in tourism. Annals of Tourism Research, 19(4), 732-751. http://dx.doi.org/10.1016/0160-7383(92)90064-V

Mechinda P., Serirat, S., \& Guild, N. (2009). An examination of tourists' attitudinal and behavioral loyalty: Comparison between domestic and international tourists. Journal of Vacation Marketing, 15(2), 129-149. http://dx.doi.org/10.1177/1356766708100820

Milman, A., \& Pizam, A. (1995). The role of awareness and familiarity with a destination: The central Florida case. Journal of Travel Research, 33(3), 21-27. http://dx.doi.org/10.1177/004728759503300304

Nunnally, J. C., \& Bernstein, I. H. (1994). Psychometric theory (3rd ed.). New York: McGraw-Hill.

Oliver, R. L. (1999). Whence consumer loyalty? Journal of Marketing, 63, 33-44. http://dx.doi.org/10.2307/1252099

Olsen, L. L., \& Johnson, M. D. (2003). Service equity, satisfaction, and loyalty: From transaction-specific to cumulative evaluation. Journal of Service Research, 5(3), 184-196. http://dx.doi.org/10.1177/1094670502238914

Oppermann, M. (2000). Tourism destination loyalty. Journal of Travel Research, 39(1), 78-84. http://dx.doi.org/10.1177/004728750003900110

Parasuraman, A., Zeithaml, V. A., \& Berry, L. L. (1994). Reassessment of expectations as a comparison standard in measuring service quality: Implications for further research. Journal of Marketing, 58(1), 111-124.

Park, C. W., Mothersbaugh, D. L., \& Feick, L. (1994). Consumer knowledge assessment. Journal of Consumer Research, 21, 71-82.

Park, J., Shimojo, E., \& Shimojo, S. (2010). Roles of familiarity and novelty in visual preference judgments are segregated across object categories. Proceedings of the National Academy of Sciences, 107, 14552-14555. http://dx.doi.org/10.1073/pnas.1004374107

Pearson, P. H. (1970). Relationship between global and specified measures of novelty seeking. Journal of Consulting and Clinical Psychology, 34, 199-204.

Petrick, J. F. (2002). An examination of golf vacationers' novelty. Annals of Tourism Research, 29(2), 384-400. http://dx.doi.org/10.1016/S0160-7383(01)00040-8

Petrick, J. F., \& Sirakaya, E. (2004). Segmenting cruisers by loyalty. Annals of Tourism Research, 31(2), 472-475. http://dx.doi.org/10.1016/j.annals.2003.12.009

Pike, S., Bianchi, C., Kerr, G., \& Patti, C. (2010). Consumer-based brand equity for Australia as a long-haul tourism destination in an emerging market. International Marketing Review, 27(4), 434-449. http://dx.doi.org/10.1108/02651331011058590

Prayag, G., \& Ryan, C. (2012). Antecedents of tourists' loyalty to Mauritius: The role and influence of destination image, place attachment, personal involvement, and satisfaction. Journal of Travel Research, 51(3), 342-356. http://dx.doi.org/10.1177/0047287511410321

Rao, A. R., \& Sieben, W. A. (1992). The effect of prior knowledge on price acceptability and the type of information examined. Journal of Consumer Research, 19, 256-270.

Ratner, R. K., Kahn, B. E., \& Kahneman, D. (1999). Choosing less preferred experiences for the sake of variety. Journal of Consumer Research, 26, 1-15.

Reichheld, F. F., \& Sasser, W. E. (1990). Zero defection: Quality comes to service. Harvard Business Review, 68(1), 105-111.

Roig, J. C. F., Garcia, J. S., \& Tena, M. A. M. (2009). Perceived value and customer loyalty in financial service. The Service Industries Journal, 29(6), 775-789. http://dx.doi.org/10.1080/02642060902749286

Rosenberg, L. J., \& Czepiel, J. A. (1984). A marketing approach to customer retention. Journal of Consumer 
Marketing, 1(2), 45-51. http://dx.doi.org/10.1108/eb008094

Shimojo, S. (2008). Subliminal impact - Contemporary world, emotional and implicitly cognitive (in Japanese). Tokyo: Chikuma Shobo.

Shoemaker, S., \& Lewis, R. C. (1999). Customer loyalty: The future of hospitality marketing. International Journal of Hospitality Management, 18, 345-370. http://dx.doi.org/10.1016/S0278-4319(99)00042-0

Snepenger, D., \& Snepenger, M. (1993). Information search by pleasure travelers. In M. A. Kahn, M. D. Olsen, \& T. Var (Eds.), Encyclopedia of Hospitality and Tourism (pp. 830-835). New York, NY: Van Nostrand Reinhold.

Steenkamp, J. B., \& Van Trijp, H. C. M. (1991). The use of LISREL in validating marketing constructs. $\begin{array}{llll}\text { International Journal of Research in } & \text { Marketing, }\end{array}$ http://dx.doi.org/10.1016/0167-8116(91)90027-5

Taylor, S. A., \& Baker, T. L. (1994). An assessment of the relationship between service quality and customer satisfaction in formation of consumers' purchase intentions. Journal of Retailing, 70(2), 163-178. http://dx.doi.org/10.1016/0022-4359(94)90013-2

Van Prooijen, J. W., \& Van Der Kloot, W. A. (2001). Confirmatory analysis of exploratively obtained factor $\begin{array}{lllll}\text { structures. Educational and Psychological Measurement, } & 61, & \text { 777-792. }\end{array}$ http://dx.doi.org/10.1177/00131640121971518

Worthington, R. L., \& Whittaker, T. A. (2006). Scale development research: A content analysis and recommendation for best practices. Counseling Psychologist, 34, 806-838. http://dx.doi.org/10.1177/0011000006288127

Yamada, Y., \& Toyama, M. (2011). Quantitative analysis of destination loyalty formation (in Japanese). Proceedings of the 26th Annual Conference of Japan Institute of Tourism Research, 121-124.

Yoon, Y., \& Uysal, M. (2005). An examination of the effects of motivation and satisfaction on destination $\begin{array}{lllll}\text { loyalty: A structural model. Tourism } & \text { Management, }\end{array}$ http://dx.doi.org/10.1016/j.tourman.2003.08.016

Yuksel, A., Yuksel, F., \& Bilim, Y. (2010). Destination attachment: Effects on customer satisfaction and cognitive, affective and conative loyalty. Tourism Management, 31(2), 274-284. http://dx.doi.org/10.1016/j.tourman.2009.03.007 